\title{
THE OTHER SIDE OF ARGENTINE FOREIGN TRADE: SOURCES FOR THE STUDY OF IMPORTS, 1880-1913*
}

AGUSTINA RAYES IGEHCS-UNCPBA-CONICET ${ }^{\mathrm{a}}$

\begin{abstract}
Historiography has payed less attention to imports than exports from the last quarter of the nineteenth century to the beginning of World War I. On the one hand, this is explained by the crucial and more visible part that exports played in fostering economic growth. On the other, the reason why imports have been less studied is the high level of disaggregation of the data available. In this paper, we analyse the official Argentine statistics as the main source for a reconstruction of imports. Then, we recalculate the balance of trade using our corrected export series. Additionally, we propose a research agenda based on gaps in the specialised literature and the possibilities given by the use of the official statistics.
\end{abstract}

Keywords: Argentina, imports, exports, balance of trade, statistics

JEL Code: F14, N56, N76

* Received 25 March 2017. Accepted 13 September 2017. The author thanks the contributors of the present special issue, as well as Eduardo Míguez, Alejandro Fernández and Roberto Cortés Conde for comments on previous drafts. The paper has also benefited from the reviews of three anonymous referees chosen by this journal. The usual disclaimer applies.

a Instituto de Geografía, Historia y Ciencias Sociales, Universidad Nacional del Centro de la Provincia de Buenos Aires, 399 Pinto St., ZIP Code 7000, Tandil, Buenos Aires, Argentina. arayes@utdt.edu, agusrayes@hotmail.com 


\section{RESUMEN}

La historiografía ha prestado menos atención a las importaciones que a las exportaciones argentinas entre el último cuarto del siglo XIX y los umbrales de la Primera Guerra Mundial. Ello puede explicarse, por un lado, porque las segundas tuvieron un rol más evidente en el crecimiento de la economía y, por el otro, por el alto grado de desagregación de los datos de las primeras. En este trabajo, hacemos una crítica de las estadísticas oficiales argentinas como fuentes disponibles para la reconstrucción de las importaciones. Luego, reestimamos la balanza comercial usando la serie de exportación corregida por nosotros. Finalmente, proponemos una agenda de investigación en base a los vacíos historiográficos y el potencial de la información estadística.

Palabras clave: Argentina, Importaciones, Exportaciones, Balanza de comercio, Estadísticas

\section{INTRODUCTION}

In the last years, there has been a renewed interest in the performance of the Latin American economies during the so-called «First Age of the Exports» (c. 1870-1930). Given the weakness of the GDP data, foreign trade statistics have been considered as a tool to understand the economic behaviour of the region in a long-run perspective (Carreras et al. 2003; Bulmer Thomas 2010; Bértola and Ocampo 2013).

Far from the pessimism about the official statistics, which prevailed after the Second World War (Morgernstern 1953), new studies have pointed out the convenience of working with official trade data even when they recommend to use it critically (e.g. Federico and Tena-Junguito 1991; Tena-Junguito 1992; Carreras-Marín 2008). Sectorial research on Latin American trade statistics have been optimistic as well (for instance, Yánez and Badía-Miró 2007; Badia-Miró and Carreras-Marín 2008; Rubio and Folchi 2012; Ducoing and Tafunell 2013).

As part of the revalorisation of commercial statistics, a previously absent concern emerged: the reconstruction of foreign trade values in order to have more reliable data, for example, in Uruguay (Baptista and Bértola 1999; Bonino-Gayoso et al. 2015), in México (Kuntz-Ficker 2007, 2010) or in Argentina (Tena-Junguito and Willebald 2013; Bonino-Gayoso et al. 2015; Rayes 2015a; Francis 2017).

In this last case, exports have been considered, according to different perspectives ranging from the dependency theory to the export-led-growth model, as the main factor in fostering Argentine economic growth during the 
process known as the «First Export Era» (c. 1870-1929), and thus have received more attention in statistical reconstructions (Bunge 1918; Cortés Conde et al. 1965; Tena-Junguito and Willebald 2013; Rayes 2015a). In contrast with this, although between 1900 and 1929 imports were equivalent to nearly a fourth of GDP (Winograd and Vèganzones 1997, p. 29; Díaz Alejandro 2002, p. 28), their statistical record has been neglected. This may be due to the more complex structure of imports, which consisted of a wide variety of items. They also had a more sophisticated scheme of tariffs in relation to exports.

Considering that critical analyses of the sources to study Argentine imports have been scarce ${ }^{1}$, the main purpose of this paper is to evaluate how reliable the Argentine official statistics of imports are, which alternative series existed and what are their limits and scopes for the period 1880-1913. The period was chosen because it considers the stage in which the Argentine economy had been more closely integrated with the international markets and also because the corrected import series begins in 1880 . Naturally, when necessary we refer to the statistics of the previous period.

By studying the official sources and the corrected series and its problems of reliability, we also present a brief review of the specialised literature. In fact, one of the main contributions of this paper is the discussion of the balance of trade, pointing out the biases of the available data.

This paper has been divided into four parts. It begins by briefly presenting the official trade statistics and testing the accuracy of import data by contrasting it with the record of seven trade partners. It then goes on to discuss what are the main characteristics and possible problems of reliability. In the next section the balance of trade is calculated with different series and this triggers a reflection of Argentine foreign trade. Finally, a research agenda is proposed based on gaps in the specialised literature and the possibilities given by the use of official statistical information or the corrected series. The paper provides a Supplementary Material (Appendix Tables A, B and C), which is on-line.

\section{THE OFFICIAL TRADE STATISTICS IN ARGENTINA AND THE ACCURACY OF THE IMPORT SIDE}

During the last decades of the $19^{\text {th }}$ century, the Argentine government improved its statistics as part of the expansion of the responsibilities pertinent to the public administration. In that way, Argentina followed a process started by France, England, the United States and Germany (Woolf 1989; Beaud and Prévost 1997; Otero 2006; González Bollo 2014; Rayes 2016).

\footnotetext{
${ }^{1}$ Probably the only exception is Fernández (2001), but this part of the dissertation remains unpublished.
} 
The Custom of Buenos Aires had developed its own statistics and debated about the import taxes since the Independence (Burgin 1960; Halperin Donghi 1977; Mentz 1991). Nonetheless, the publication of Argentine official trade statistics began in 1861. Moreover, it was not until 1880, when Francisco Latzina took over as Director of the Statistics Office, that the statistics became more organised ${ }^{2}$. From then onwards, not only were current foreign trade values published, but also a retrospective set about the beginning of the 1860s. The statistical publications received different names though we will refer to them as ADGEN (the acronym for Anuarios de la Dirección General de Estadística de la Nación).

As we have previously stated, the official foreign trade statistics have been the main source to study how the Argentine economy progressed, which were the country's most important trade partners, what was bought and sold, etc. In fact, the ADGEN presented the annual data plus quinquennial or decennial tendencies, calculated in order to observe patterns without temporary fluctuations (ADGEN 1902, p. XXI).

The official foreign trade statistics served several purposes. On the one hand, they were an input for the policy-making process; for example, to discuss the level of protection, to know more about the state's main source of income, to debate over the modernisation of the economy, to examine international relations, etc. On the other hand, they were a testimony of Argentina's economic growth since it showed how the domestic production was diversified, how consumption patterns were sophisticated and to what extent there were goods that had been bought abroad oriented towards industrial development and the construction of infrastructure.

Of course, those who were in charge of the statistical construction were proud of their work, even when they recognised that there were obstacles to reaching a perfect accuracy. Yet, how accurate were the official records of imports? As we know, the singularity of international trade statistics is that they offer a double independent record of the same transaction. However, there are many reasons for divergence when comparing the data.

One of the most studied obstacles presented by that divergence is the geographic assignation. Platt (1971, p. 119) stated that Latin American trade figures in the $19^{\text {th }}$ century were founded on the assumption that the national origin of imports was generally the last port of shipment. This assumption took no account of international trade routes, so entrepôts or ports of transit often appeared in the statistics as the main source. As we will see, this was a problem in Argentina's official records.

But geographic assignation was not the only problem. Federico and Tena-Junguito (1991, pp. 261-263) have grouped the reasons for divergence

${ }^{2}$ In a letter sent to the General Director of Revenue, Latzina remarked on the dramatic situation in which he found the statistical archive. Latzina also emphasised the scarcity of significant information like navigation data (ADGEN 1880, p. 3). 
between partners' records into three headings: «unavoidable» (different costs of exporting compared to importing); «structural» (differences in trade coverage, classification of goods, recording of values and indication of trading partners) and «errors» (by negligence or fraud).

Before describing the characteristics of the ADGEN and studying their possible reliability problems, it is necessary to test the accuracy of the import data. To do this, we use, on the one hand, the information provided by Vázquez Presedo (1971, p. 196), who, following the European and North American official trade statistics, compiled the total values of exports to Argentina recorded by its seven main partners (the United Kingdom, France, Germany, the United States, Belgium, Italy and Spain), which represented between 70 per cent and 85 per cent of total import value, in millions of pounds between 1881 and 1912. The values were registered as free on board (f.o.b.). On the other hand, we worked with the Argentinean official records of imports of those partners which were registered as cost, insurance and freight (c.i.f.). As they are in pesos fuertes or in pesos oro, we converted them into pounds. Finally, as the information is presented here in U.S. dollars, we converted all into this currency following the proposal of Federico and Tena-Junguito (2016). The results are in Appendix Tables A and B.

Naturally, the values considered by the pair of partners should not perfectly match since one is recorded as c.i.f. (Argentina) and the other as f.o.b. (its partners). But what difference is to be expected? Federico and Tena-Junguito (1991, p. 264) estimated as acceptable a larger interval of confidence of 100-120 per cent for imports. That is to say, the imports should be up to 20 per cent more expensive than exports given the costs of the former. Figure 1 reports the results by each pair of countries.

The countries with the best correlation between statistical records were the United Kingdom, Germany and France. And the countries in which there was worse correlation between the statistics were the United States, Belgium, Spain and Italy. According to its main trade partners, the ADGEN tended to overvalue the transactions with Germany until the 1890s and with the United Kingdom, the United States, Belgium, Italy and Spain just before the turn of the century. By contrast, the ADGEN tended to undervalue the trade with France as far as 1892. It is risky to answer unequivocally here why with some countries there were better results than with others. This could have been due to more consolidated statistical systems or to the role of transit ports such as Antwerp. Nevertheless, it is important to remark that the lack of accuracy might not have been exclusively the responsibility of the ADGEN, since the registries of the commercial partners might have had reliability problems as well. In fact, the literature has considered import records more reliable than geographical exports assignment because of the duty discrimination (Federico and Tena-Junguito 1991, p. 263).

Figure 2 shows the outcome of comparing the total sum of Argentina's import records and the corresponding export statistics of its partners (the seven countries mentioned above). 
FIGURE 1

ACCURACY TESTS OF ARGENTINE IMPORTS BY PAIR OF COUNTRIES, 1881-1912
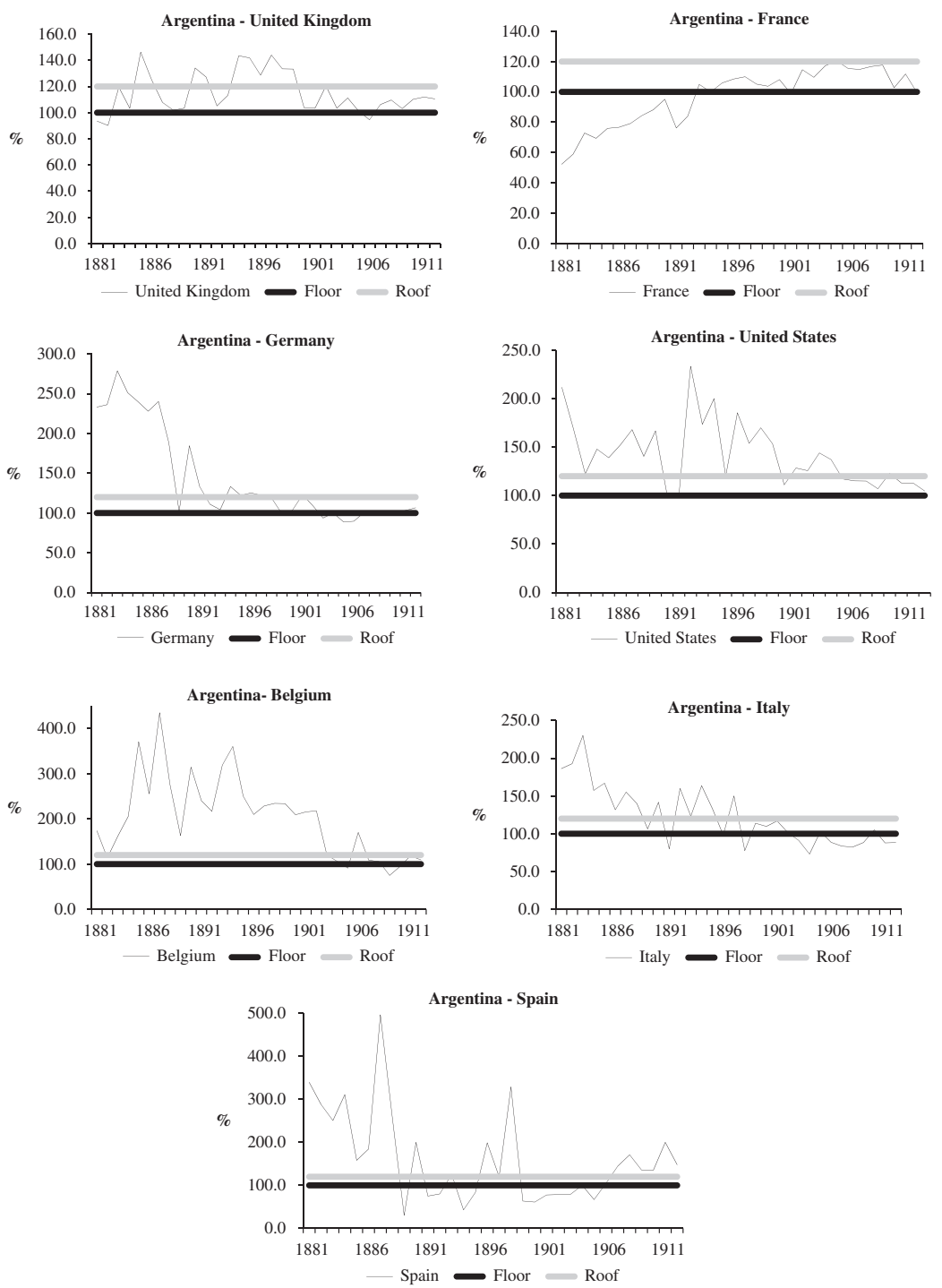

Note: The vertical axis represents the percentage difference between the total value imported by Argentina of the trading partner (c.i.f.) and the total value exported by the same partner to Argentina (f.o.b.). The expected range is 100 per cent to 120 per cent, that is, imports are expected to be up to 20 per cent more expensive than exports.

Sources: Anuarios de la Dirección General de Estadística de la Nación (ADGEN) (1881-1912) and Vázquez Presedo (1971, p. 196). 
FIGURE 2

ACCURACY TEST FOR SEVEN PARTNERS, 1881-1912

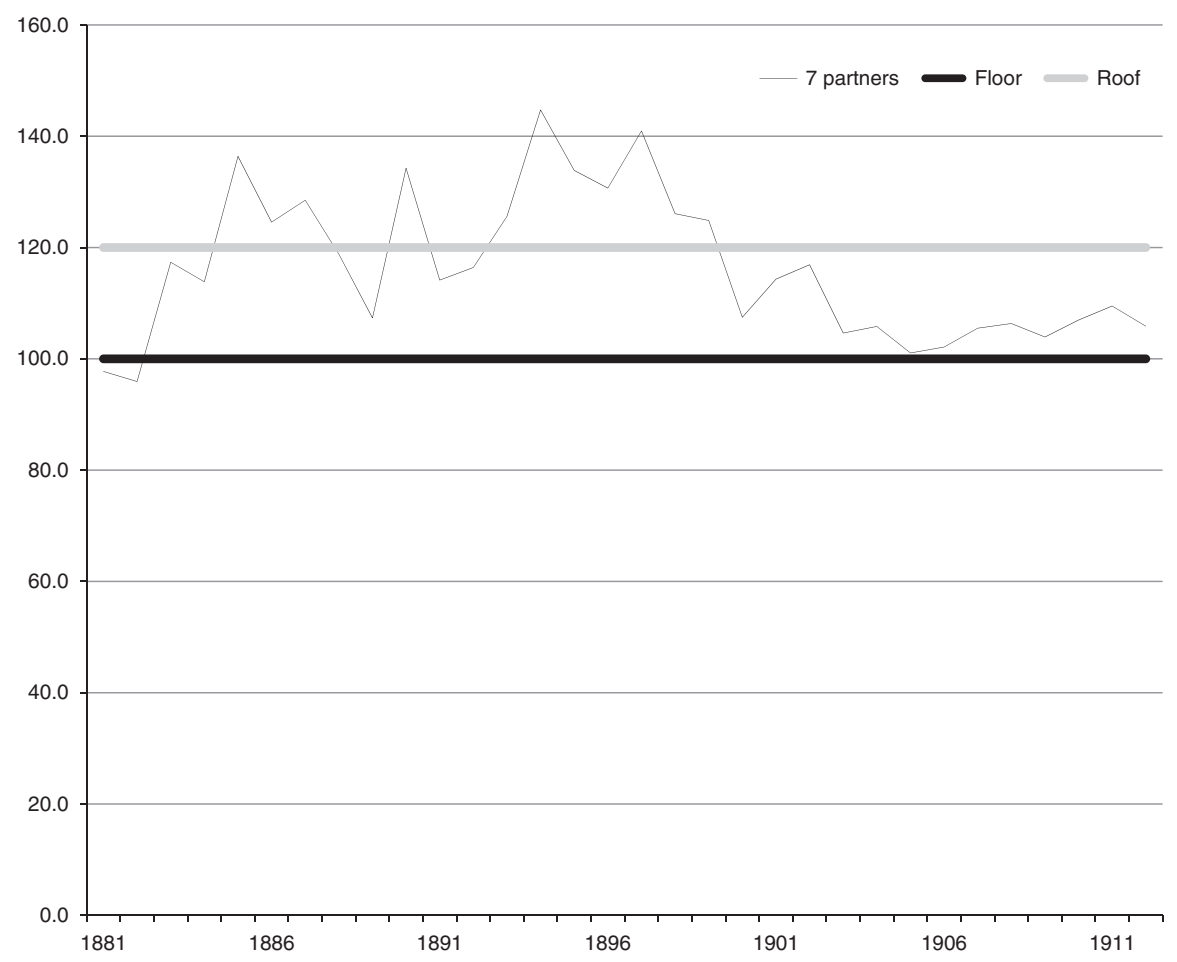

Notes and sources: See Figure 1.

As Federico and Tena-Junguito (1991, p. 264) concluded, the aggregate results are better than bilateral ones. The averages of the former are stable in time and close to the norms. This shows that errors of geographical assignation were one of the main obstacles of accuracy and that the import records were reliable. In fact, the results of this last exercise confirmed that Argentina's import records were better than its export records, which was to be expected given the relevance of the imports in the Argentine tax scheme of the time. Tena-Junguito and Willebald (2013) and Carreras-Marín and Rayes (2015) have compared Argentine official export records with the import records of its main trade partners (the United Kingdom, Germany, France and Belgium, and the United Kingdom, Germany, France, Belgium, Spain, Italy, Brazil and the United States, respectively). The results of both exercises proved that the ADGEN tended to undervalue exports. But the lack of accuracy was higher than what is shown in Figure 2. If we expect the value of 
exports to be up to 20 per cent lower than the value of imports, in some years the difference was greater than 100 per cent.

Figure 2 reveals that Argentina's import records diverged at most by 40 per cent from the export register of its trading partners considered as a whole. Nevertheless, what is notable is that the ADGEN tended to overvalue the imports before the turn of century and undervalue them since then. This problem can be explained by the hypothesis, which we develop below, that official prices were not updated. Therefore, they could be higher than the real prices when international prices fell (1870-1895) and lower when they grew (1895-1913).

In the next section we examine the characteristics of the ADGEN. Our purpose is to do a critical analysis of the official statistics as sources to study imports. Thus, as far as possible, we will suggest alternative ways in order to improve the reliability of the data.

\section{DESCRIBING THE ADGEN (ANUARIOS DE LA DIRECCIÓN GENERAL DE ESTADÍSTICA DE LA NACIÓN): SCOPE AND LIMITATIONS OF IMPORT RECORDS}

\subsection{The currency}

Until 1882 the amounts were expressed in pesos fuertes (some trade operations were done with Latin American currencies but they were not significant), a convertible currency. From 1883 Argentina adopted the goldstandard, although the currency was inconvertible between 1885 and 1902 (for a detailed explanation of the process and the Law of Convertibility of 1899, see Ford 1966; Della Paolera and Taylor 2003), and the information was expressed in pesos oro. Considering that the use of different exchange rates could introduce distortions in terms of reliability and comparability (Federico and Tena-Junguito 1991, p. 263), we have transformed the total value of imports into U.S. dollars, as is proposed in Federico and TenaJunguito (2016). Taking a long-run perspective in mind, these authors stated the convenience of providing the information in U.S. dollars since they maintained the parity with the gold standard even after World War I. The results are shown in Figure 3 (for an annual series, see Appendix Table C).

\subsection{Prices and values}

The trade statistics are based on «official values» or on «declared values». The latter was adopted in the United Kingdom during the $19^{\text {th }}$ century, and it was progressively accepted in the rest of Europe after World War I (Federico and Tena-Junguito 1991, p. 261). The former was widely used by Latin American countries and Argentina sustained it until 1941. Both systems are questionable. While official prices are not constantly updated and they 
assume certain uniformity among different goods assembled under the same name, declared values depend on the diligence and knowledge of the shippers' clerk (Platt 1971, p. 124).

In the Argentine case, the failure in the official valuation system was studied on the export side. The directors of the ADGEN noted the limitations in using official prices at least up to 1916 (Latzina 1905; Bunge 1918). Fifty years later, Cortés Conde et al. (1965) corrected the values by replacing the official prices with export prices in Buenos Aires. Recently, a debate on the convenience of using foreign or local prices to supplant the official ones has taken place (for further details, see Tena-Junguito and Willebald 2013; Rayes 2015a).

According to ADGEN, the official prices of imports were ad-forum official values, which means that, in theory, official prices should correspond with market prices. Although it was an obligation of Congress, in fact, the General Direction of Revenues was in charge of ad-forum values, and then the different customs assigned the ad-forum values to each product. Thus, the imports were recorded in the official returns at values assigned to them on official lists prepared by a commission composed of members of the Commerce Chamber or of commercial, state or industrial delegates, who discussed the lists with the General Direction of Customs. The debates were intense since the taxes were paid in relation to prices. The Argentine industrials were both producers and importers; therefore, they lobbied the government to achieve protectionist ad-forum values while competing, and liberal ones when trading (Hora 2000).

The import taxes were so relevant that, for example, during the 1880s the lists of ad-forum values were updated to increase the prices by around 15 per cent because of fiscal reasons - the duties were paid in pesos moneda nacional, which were inconvertible (ADGEN 1889, p. IV). After the crisis of 1890 taxes were collected in pesos oro.

Latzina believed that the ADGEN contributed to an analysis of which industries progressed and which regressed. It also served to design customs legislation. Nevertheless, he noticed that it had valuation problems and he recognised that it was not possible to arrive at an exact knowledge of import prices because of the variety of goods (ADGEN 1882, p. V). In 1891, Latzina asserted that the values used were "close to the truth» (ADGEN 1891, p. IV). One year later, he insisted that the prices were grosso modo effective (ADGEN 1892, p. XV).

That claim does not coincide with Platt (1971, p. 125), who suggested that the official values of Argentine imports were, on average, nearly 50 per cent too high since official prices of sugar, rice, beer, kerosene and tea were higher than real prices. Martinez and Lewandowski (1911, p. 215) also estimated that official values on Argentine imports were overvalued by 20 per cent or 30 per cent because of the arbitrary nature of the customs valuations. The most likely cause for the overvaluation was that the 
FIGURE 3

TOTAL VALUE OF IMPORTS, 1880-1913 (IN MILLIONS OF U.S. DOLLARS)

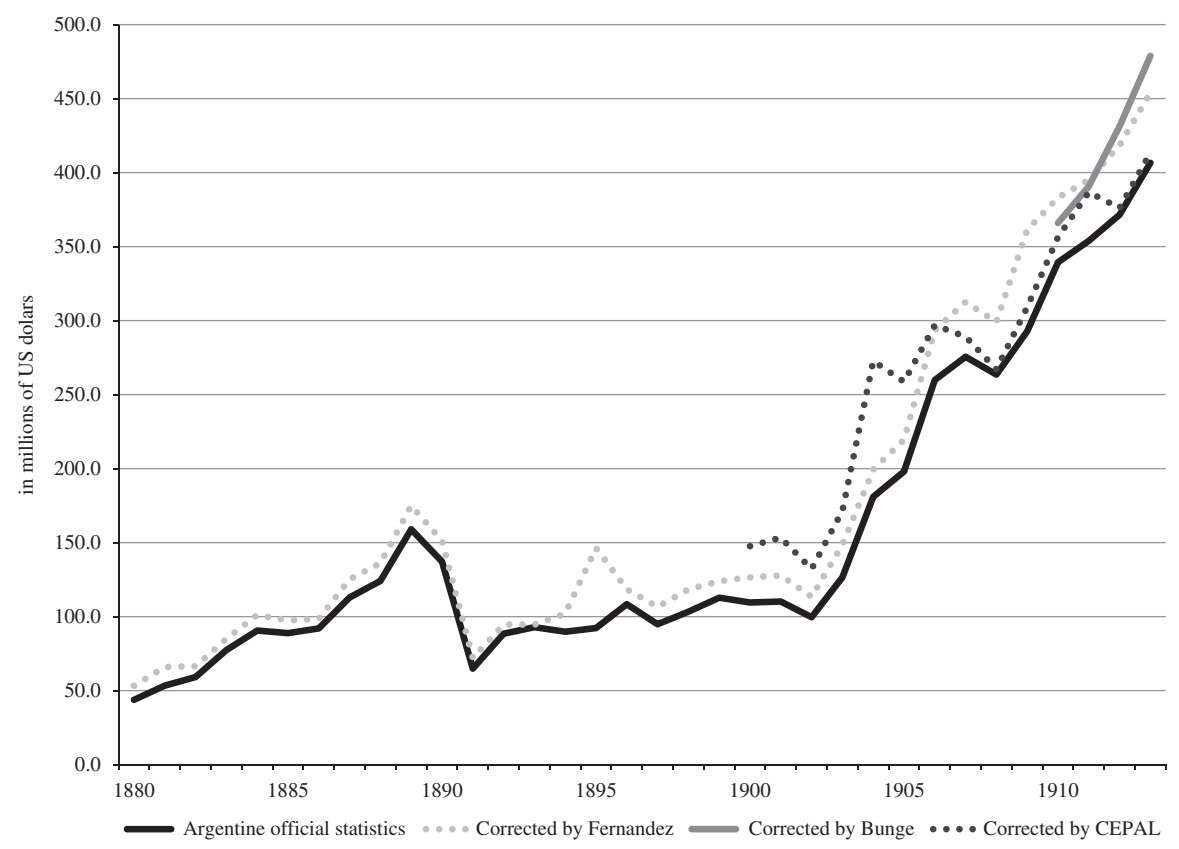

Sources: Anuarios de la Dirección General de Estadística de la Nación (ADGEN) (1880-1913), Bunge (1918), CEPAL (1958) and Fernández (2001).

Argentine state depended on import taxes, given that they represented, for example, 55 per cent of total income in 1910 (Latzina 1914, pp. 74-75). Besides, the scarcity of human and material resources might have complicated the updating of prices.

The correction of official values has been almost entirely lacking with three exceptions. First, Bunge (1918) made a retrospective correction from 1910 to 1917 . The revised CIF prices were obtained from quarterly surveys that the statistical office made of the main importers of Buenos Aires. Surveys were made of 170 items representing about 70 per cent of the total imported value. At the declared price the import tariff and importer's profit margin were subtracted. The annual CIF prices were calculated as averages of the four quarters. Then, each official price was multiplied by its imported volume and all were aggregated, as were all the imports valued at their «real» prices. The difference between both aggregates provided a deviation coefficient that was used to correct the official import series. Bunge's results for the period 1910-1913 are in Figure 3 (for an annual series, see Appendix Table C). 
The next attempt to correct the import series was made by the Economic Commission for Latin America and the Caribbean, who re-estimated the total value from 1900 to 1950 , using a price index based on prices of the year 1950 (CEPAL 1958). The results, converted from pesos moneda nacional to U.S. dollars, are in Figure 3 (for an annual series, see Appendix Table C).

More recently, Fernández (2001, pp. 467-478), who studied the link between Spanish immigration to Argentina and Argentine imports during 1880-1935, constructed an import series. It was based on an average of the CIF prices for forty items revised by Bunge for the period 1910-1912. These results, which were transformed from pesos oro into U.S. dollars, are in Figure 3 (for an annual series, see Appendix Table C). As in Bunge's series, the series of Fernandez reveals undervaluation of the official one. This may be explained because the prices used were taken from a period in which they were increasing.

The differences between series, which we will analyse in the section 4 , can be followed in Figure 3.

\subsection{Volume}

In Argentina, all imported or exported goods were measured or weighted. It was never enough just to have the trader's declaration. However, there was probably less control over the exports or imports without any tariffs (Platt 1971, p. 128). Once the goods were measured or weighted, custom officials deduced packaging according to the tarifa de avalúos. Thus, the ADGEN were compiled from documents whose accuracy depended on the customs authorities (ADGEN 1892, p. XV).

In general, volume has been considered more reliable than value. Fortunately, the ADGEN tended to present the information as meticulously as possible, even when certain goods were recorded in two or three different units of measurement (ADGEN 1898, p. XVI). For example, the volume of alcoholic beverages was expressed both in bottles and in litres and the volume of textile pieces was computed in kilograms, boxes or packages (ADGEN 1897, pp. 24-50). The problem of different units of measurement was progressively solved.

In general, the literature was confident about the recorded volume despite the problems of comparability already pointed out - because the vast majority of goods paid taxes (Fernández 2001, p. 458). However, as the tariffs affected the imports in different ways, we understand that sectorial studies would shed light on the reliability of volume in each case.

\subsection{Smuggling}

Smuggling has been indicated as one of the reasons why comparability is not perfect in foreign trade statistics (Carreras-Marín 2008). The problem has 
been connected to the payment of taxes (Kellenber and Levinson 2016). The men who prepared the ADGEN believed that a small amount of smuggling could exist; given that Argentina's coasts were large and there was not a large enough customs police to control them (ADGEN 1892, p. XVI). However, it was argued that contraband trade was largely limited to luxury goods (Pillado 1906, pp. 340-341).

\subsection{The classification of imports}

One of the problems in the comparability of foreign trade statistics is the classification of products. There is no great difficulty in the description and classification of primary articles. But the classification of many other goods, specifically manufactured products, creates a wide possible range of interpretations (Platt 1971, p. 126). Therefore, in Argentina the classification of imports was more complex than the classification of exports, given the heterogeneity of goods and the scarcity of human and material resources employed to record them (ADGEN 1897, p. XII).

Since the decade of 1860 the imports were registered in alphabetical order without any kind of categorisation. The classification became more sophisticated since 1880 because at the beginning not all goods were being imported and some of them were irrelevant. Obviously, it was necessary to adapt the classification to the movement of imports. First, the classification was oriented to distinguish the type of goods; that is, if they were for consumption or for use in domestic industries (ADGEN 1880, pp. 38-39). Latzina emphasised that the nomenclature should be adapted to the tarifa de avalúos, without considering the classification done by Europe or the United States because their economies were different from Argentina (ADGEN 1884 , p. XXXIV). At the end of the $19^{\text {th }}$ century, the best criterion was to classify the products by their nature (ADGEN 1897, p. IX). Table 1 shows the evolution of the imports following the classification of 1913.

Although indicative, that division is not enough to know exactly how many goods can be catalogued as industrial investments inputs or not. To calculate it, it is necessary to disintegrate the main categories. This exercise was initially done by the report presented by ECLAC (CEPAL 1958, p. 110), which separated the products into non-durable consumption goods, durable consumption goods, fuels and lubricants, metallic intermediate products, other intermediate products, material for construction, machinery for agriculture and machinery for industries. Then, Ford (1966, p. 240) distinguished between imports for consumption and imports for investments, and Vázquez Presedo (1971, pp. 197-208) differentiated among consumption goods, capital goods and raw materials. All of those divisions were made arbitrarily by each author using the Argentine official statistics and they did not necessarily explain how they made the new classification. Therefore, it would be useful to construct main categories of imports with explicit and detailed criteria. 
TABLE 1

COMPOSITION OF IMPORTS, SHARES ON TOTAL VALUE IMPORTED (\%), 1883, 1893, 1903 AND 1913

\begin{tabular}{|l|r|r|r|r|}
\hline Classification according to ADGEN & $\mathbf{1 8 8 3}$ & $\mathbf{1 8 9 3}$ & $\mathbf{1 9 0 3}$ & $\mathbf{1 9 1 3}$ \\
\hline Animals & 0.4 & 0.2 & 0.4 & 0.3 \\
Food & 1.4 & 11.2 & 9.5 & 8.3 \\
Tobacco & 1.5 & 0.4 & 2.9 & 1.7 \\
Beverages & 11.6 & 8.6 & 5.7 & 3.3 \\
Fabrics and clothing & 26.7 & 33.9 & 30.7 & 21.3 \\
Oils and fats & & & 3.6 & 5.6 \\
Chemical and pharmaceutical products & 3.2 & 4.3 & 3.5 & 3.6 \\
Dyes & & & 0.7 & 0.6 \\
Woods & 4 & 5.1 & 6.5 & 2.6 \\
Paper & 1.7 & 3.2 & 2.5 & 2.4 \\
Leather and fur & 1.5 & 0.9 & 1 & 1.1 \\
Iron & 9.4 & 13.5 & 18 & 11.9 \\
Other metals & 6.7 & 1.6 & 2.9 & 3.4 \\
Agriculture & & & & 2.2 \\
Transport & & & & 8.8 \\
Stones, crystals, ceramic and others & 2.8 & 2.4 & 9.1 & 8.7 \\
Building & 9.3 & 3.4 & & 8.5 \\
Electricity & & & & 2.4 \\
Various articles and manufactures & 19.8 & 11.3 & 3 & 3.3 \\
Total value of imports (in millions of U.S. dollars) & 77,4 & 92,9 & 126,6 & 406,6 \\
\hline
\end{tabular}

Notes: In 1883 and 1893 the oils and fats were included within chemical products. In 1883, 1893 and 1903 the items considered as agriculture products were encompassed between iron goods. Additionally, during those years the products included in transport were incorporated in wood and stones. Electricity became more relevant in 1913.

Sources: Anuarios de la Dirección General de Estadística de la Nación (ADGEN) (1883, 1893, 1903 and 1913).

\subsection{The origin of imports}

In the analysis of foreign trade statistics, one of the most studied problems is the geographical assignation. In Argentina, the record of exports had several difficulties: they were recorded by their port of destination which was not always the final destination, there existed a category named exports «by orders», some goods were transhipped in Montevideo, etc.

As we showed before, when we compared the official Argentine imports with the official main partners' exports we found out that the differences were generally higher than should have been possible. That is to say, even 
when we discounted the costs of freight, insurances and others import costs, the difference was more than to be expected and, what is worse, partners' records of exports were higher than Argentine records of imports. This situation is explained by several reasons.

First, the ADGEN recorded the maritime origin of imports, which was not always their real origin. The official statistics considered only the port of departure, ignoring any previous itinerary. This affected imports coming from Switzerland, Norway and Austria, such as crystal, textiles, china or wood, which were recorded as originating from Germany, France, Belgium or England (ADGEN 1884, p. XXIV, 1888, p. XXI). This probably happened because Argentina did not have a merchant navy (ADGEN 1882, p. XIII).

Second, there existed a category named «in transit» which included any product entered by a port, for example, Buenos Aires, but on its way to another Argentine customs port, for example, Rosario, where it paid the taxes. Thus, in the official statistics its final destination was recorded but not its origin (ADGEN 1880, pp. 5-6).

Third, some imports which came from South American ports, particularly Montevideo, were recorded as originally from there when they were really European (ADGEN 1880, p. 7, 1892, p. XV). A recent study proved that the Uruguayan and Argentinean official statistics were distorted because of the transit trade (Bonino-Gayoso et al. 2015). Over the years, the ADGEN avoided imports from other countries that were registered as Uruguayan (ADGEN 1896, pp. VIII-X). Some products were easily recognisable, such as wine of Bordeaux. It also helped that the port of Buenos Aires was modernised because the goods then arrived directly without transhipping in the port of Montevideo, which had been better until the 1880s given its greater draught.

To improve the knowledge about Argentinean foreign trade, the statisticians requested collaboration from diplomats (ADGEN 1880, p. 7), but it did not work. Actually, it has already confirmed the problems of using diplomatic sources as a quantitative complement of ADGEN because of the different units of measurement, exchange rates, calendar years, etc. (Rayes 2013).

In spite of the problems of geographic assignment, at the end of the $19^{\text {th }}$ century Argentina's official statistics had made great progress (ADGEN 1896, p. VIII, 1899, p. XIV). On the one hand, the percentage assigned to Uruguay declined. For instance, it was 5.5 per cent of total import value in 1887 and it dropped at 0.5 per cent a decade later. On the other hand, the percentage considered as «other countries» also went down. Since 1902 new customs legislation contributed to know more about imports arrived from Austria, Canada, Colombia, China, Demark, Ecuador, Egypt, Greece, Haiti, Japan, Morocco, Mexico, Russia, Switzerland, Turkey and Venezuela (ADGEN 1902, p. XVI). These improvements can be observed in Table 2 and might be the reason why the literature largely uses the information of the official geographic assignation of the imports (for instance, Fodor and O'Connell 1973; Caputo de Astelarra 1984). 
TABLE 2

SHARE OF ORIGINS IN TOTAL IMPORT VALUE (\%) AND TOTAL VALUE OF IMPORTS (IN MILLIONS OF U.S. DOLLARS), 1883, 1893, 1903 AND 1913

\begin{tabular}{|c|c|c|c|c|c|c|c|c|c|c|}
\hline Year & Germany & Cuba & Austria & Belgium & Bolivia & Brazil & Chile & Spain & $\begin{array}{l}\text { United } \\
\text { States }\end{array}$ & $\begin{array}{c}\text { Total value } \\
\text { of imports } \\
\text { (in millions } \\
\text { of U.S. } \\
\text { dollars) }\end{array}$ \\
\hline 1883 & 8.7 & 0.1 & & 4.1 & 0.1 & 2.7 & 0.3 & 4.7 & 6.1 & 77.4 \\
\hline 1893 & 11.5 & & & 10 & 0.1 & 2.2 & 0.3 & 3.3 & 10 & 92.9 \\
\hline 1903 & 13 & 0.3 & 0.5 & 4.2 & 0.1 & 4.1 & 0.2 & 2.7 & 12.7 & 126.6 \\
\hline 1913 & 16.9 & 0.3 & 1.4 & 5.2 & 0.1 & 2.2 & 0.2 & 2.9 & 14.7 & 406.6 \\
\hline Year & France & Italy & $\begin{array}{l}\text { The } \\
\text { Netherlands }\end{array}$ & Paraguay & $\begin{array}{c}\text { United } \\
\text { Kingdom }\end{array}$ & Sweden & Uruguay & $\begin{array}{c}\text { Other } \\
\text { countries }\end{array}$ & \multicolumn{2}{|c|}{$\begin{array}{c}\text { Total value of imports } \\
\text { (in millions of U.S. } \\
\text { dollars) }\end{array}$} \\
\hline 1883 & 19.2 & 4.3 & 0.7 & 1.6 & 38.2 & 0.01 & 5.5 & 3.6 & \multicolumn{2}{|c|}{77.4} \\
\hline 1893 & 13.2 & 9.7 & 0.2 & 1.2 & 33.8 & 0.02 & 2.7 & 1.8 & \multicolumn{2}{|c|}{92.9} \\
\hline 1903 & 9.7 & 11.2 & 0.6 & 0.8 & 34.2 & 0.02 & 0.6 & 5.3 & \multicolumn{2}{|c|}{126.6} \\
\hline 1913 & 9 & 8.3 & 1 & 0.5 & 31.1 & 0.005 & 0.8 & 5.4 & \multicolumn{2}{|c|}{406.6} \\
\hline
\end{tabular}

Source: See Table 1. 


\subsection{Errors of customs officials}

The foreign trade statistics can be distorted by errors made, willingly or not, by customs officials (Carreras-Marín 2008). According to Latzina, this problem was less likely in Buenos Aires, which received between 75 per cent and 85 per cent of total import value, than in other customs houses (ADGEN 1898, p. XIII, 1902, p. XIII, 1906, p. XVIII).

One of the most common mistakes was to date the imports. Considering the date of landing contributed to knowing how much Argentina had imported in a certain year, whereas considering the date of taxes payment contributed to knowing how much the import meant for fiscal purposes. Latzina suggested recording the imports by the second criterion (ADGEN 1880 , p. 6). Another mistake was that some customs officials did not correctly classify the products (ADGEN 1895, pp. V-VI).

\section{ARGENTINE FOREIGN TRADE REVISITED}

Up until now, we have studied one of the sides of Argentine foreign trade during the First Globalisation: exports. We have reconstructed a new series, we have recreated the export basket and we have re-estimated the geographical assignation of the main exports. We based our results on Buenos Aires market prices and in a distribution of the so-called «exports by orders» (Rayes 2015a). By doing so, we have come to the conclusion that between 1875 and 1929 Argentine exports grew, beyond their fluctuations, because they neither depended on a single market nor a unique product.

Figure 4 shows the differences between official series, our series and the one constructed by Tena-Junguito and Willebald (2013), who used London market prices adjusted to Argentine border by a freight factor to correct the undervaluation of official prices. All of the series were in pesos oro and we have converted them into U.S. dollars (for an annual series see Appendix Table C).

There existed a consensus that the official series of exports during the studied period tended to be undervalued although, as it can be seen in Figure 4, our series considered that the official ones were overvalued for a short period (1885-1894). The main discrepancy between the series is that since the 1880 s and until the end of the $19^{\text {th }}$ century Tena and Willebald' series show much more dynamism than ours. It might be explained by the different markets from which each one has derived the prices to revise the official series since both used the official volume. Clearly, after the turn of the century the three series tended to converge beyond slight differences in level. Regardless of each series, Argentine exports tended to grow between the last decades of the $19^{\text {th }}$ century and the years before World War I. In fact, the rate of annual growth between 1880 and 1913 was around 6.1 per cent 
FIGURE 4

TOTAL VALUE OF ARGENTINE EXPORTS, 1880-1913 (IN MILLIONS OF U.S. DOLLARS)

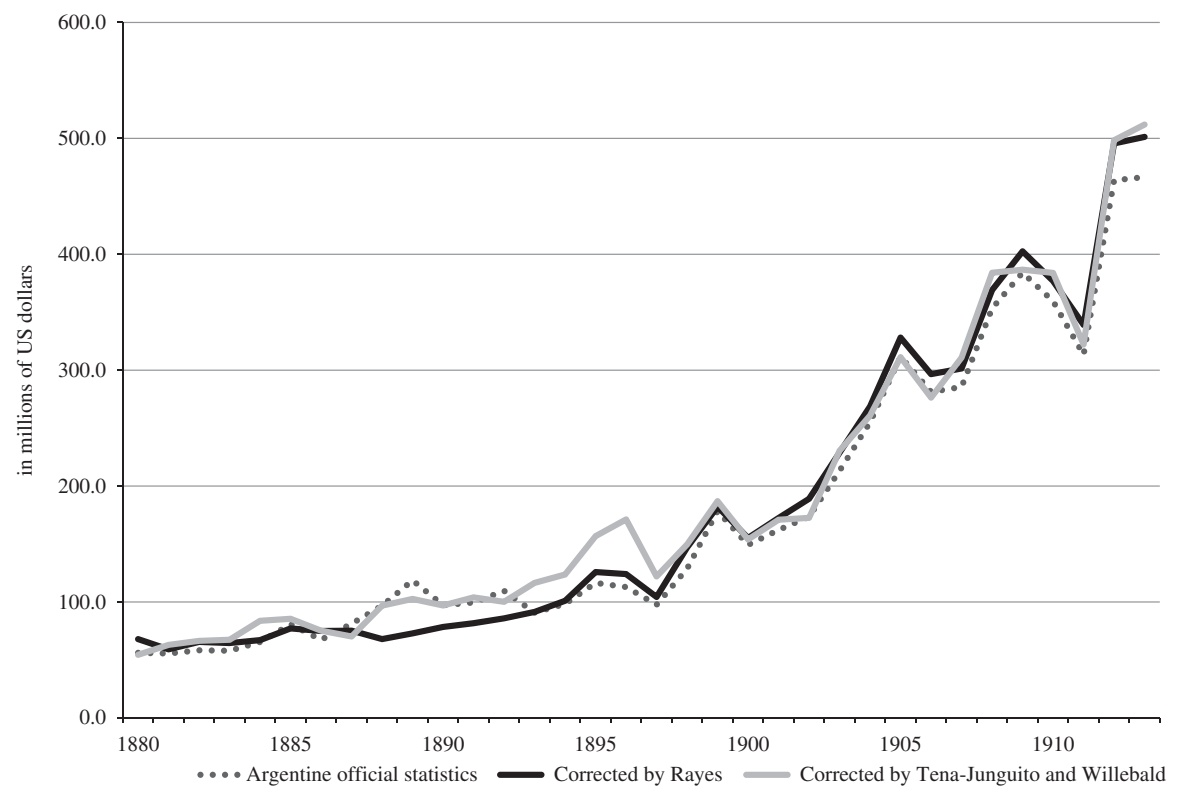

Sources: Anuarios de la Dirección General de Estadística de la Nación (ADGEN) (1880-1913), Tena-Junguito and Willebald (2013) and Rayes (2015a).

and 6.8 per cent, depending on the chosen data. Given that the procedure of our series is known to us and that its results have been tested and shown to be more reliable than the official series, the next estimations will be based on this series.

The literature has marked different factors which justify the increase of exports, both in values and volume ${ }^{3}$, for instance: the fall of domestic and transatlantic transport cost (Gerchunoff and Llach 2008; Bértola and Ocampo 2013), the development of new agricultural production (Cortés Conde et al. 1965; Cortés Conde 1979), the extension of the frontier (Míguez 2008), the modernisation of infrastructure (Cortés Conde 1974), the development of forward linkages in the export sector (Geller 1975), supply and demand forces (Cortés Conde 2003), a wide range of products and markets in comparison with other Latin American countries (Díaz Alejandro 2002;

\footnotetext{
3 For an extended review of the sources and the literature to study the exports between the last quarter of $19^{\text {th }}$ century and the Great Depression, see Rayes (2015b).
} 
Bulmer Thomas 2010; Badía-Miró et al. 2016) or «new settlement» economies (Míguez and Rayes 2014).

Even in an initial stage, in this new research we have set out the characteristics of the sources to study the less known side of Argentina's foreign trade: imports. As has been shown in Figure 3, those who corrected the official import series demonstrated that it was undervalued. Nonetheless, it is relevant to indicate that this diagnosis did not coincide with the observations of Platt (1971) nor Martinez and Lewandowski (1911), for whom, as it was previously described, the official import series was overvalued. Therefore, it is necessary to check the prices during the whole period because it might be possible that the official series was overvalued in some years and undervalued in others, without a unique trend, as we have already proved in the export series. Until we can do so, we have verified that the official series of imports can be used with reservations. If the accuracy test by pair of countries provides pessimistic results (Figure 1), the accuracy test for the seven partners (Figure 2) is more optimistic over the official import series. Additionally, it is possible to contrast the results of the official import series with the corrected ones in order to improve our ideas on Argentine foreign trade.

The rate of annual growth of imports between 1880 and 1913 was about 6.8 per cent according to official data (almost identical rate to the data of Fernandez, for whom it was 6.5 per cent). Beyond some differences in levels, certainly not very large, both the official series and the one calculated by Fernandez indicate that Argentine imports grew until 1890. As Martinez and Lewandowski (1911, p. 212) had pointed out, the imports were usually larger than exports from 1861 onwards because the external credit allowed Argentina to increase its power of purchase above its actual resources. Foreign borrowing, largely destined for investment, necessarily increased the demand of imports, while the surge in immigration also tended to increase the demand of consumer goods. After the great fall of 1891, which might be explained by the country's default due to the so-called "Baring crisis», the imports tended to grow but they did not recover the performance of 1890 until 1904. Ford (1966, pp. 149-155) proved that the import of investment goods was expanded following the changeable flows of external credit. Thus, they declined during the 1890 s and increased at the beginning of the $20^{\text {th }}$ century, which is consistent with Table 1 .

Figures 3 and 4 are really eloquent about the growth of the Argentine foreign trade. Regardless of which series one might deal with, it was multiplied by more than eightfold between 1880 and 1913. As Argentina became a competitive exporter of raw material and food, it was an importer of raw material and manufactures. According to Winograd and Vèganzones (1997, p. 29), between 1900 and 1929 the degree of trade openness (estimated as total trade to GDP) was about half of GDP. The development of the Argentine trade should be understood as a circle. While the exports allowed the payment of imports, it is relevant to say that a significant percentage of the 
FIGURE 5

THE BALANCE OF TRADE IN ARGENTINA, 1880-1913 (IN MILLIONS OF U.S. DOLLARS)

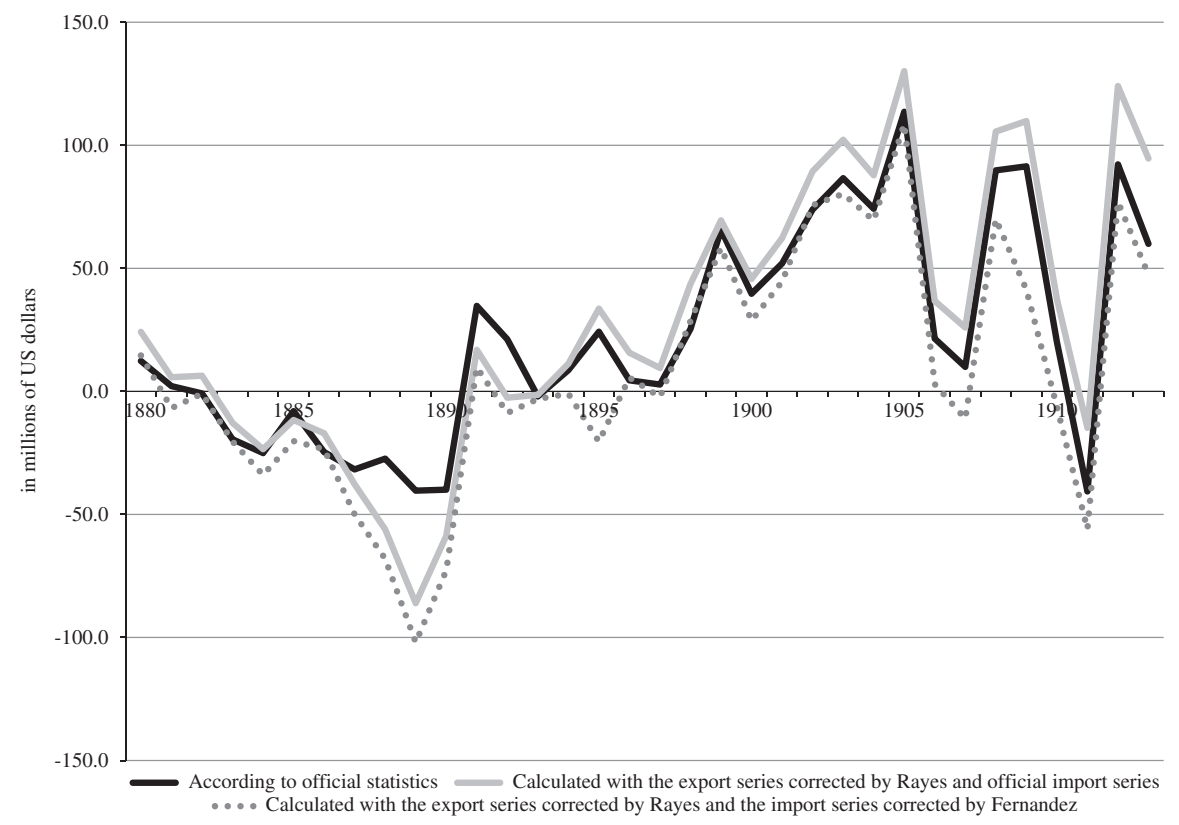

Sources: Anuarios de la Dirección General de Estadística de la Nación (ADGEN) (1880-1913), Fernández (2001) and Rayes (2015a).

imports, around half of the total value, was related directly or indirectly with the export sector (Kuntz and Rayes unpublished).

In the period, Argentina depended on its exports to pay for its imports and the interest of its foreign debt. The balance of trade was a significant variable for Argentina's economy. Figure 5 illustrates the balance of trade, calculated by official series and estimated with our corrected export series, both with the official import series and with the one constructed by Fernandez.

On the one hand, considering the official import series, in both estimations (the one with official export series and the other with our corrected export series) during the whole period there are differences in levels (only in 1882 and 1892 the balances have different signs). Until 1884 the balance of trade calculated with corrected prices shows a better performance of exports and between 1885 and 1892 a more intense fall in exports. This is because the official prices, due to their lack of updating, did not record the fall in international prices of the products that Argentina sold in foreign markets, particularly wool and leathers. The estimation done with corrected export 
series for the later 1880 s and the beginning of the 1890 s seems to be consistent with the crisis repeatedly pointed out by the literature (for instance, Ford 1966, pp. 225-241; Gerchunoff and Llach 2007, pp. 50-53; Regalsky 2011, pp. 183-184). Actually, the balance of trade estimated with corrected export series marks a greater deficit than that considered with the official data.

The deficit during the 1880s had been traditionally associated to the remarkable development of imports, which coincided with large borrowings. According to Williams (1969, p. 46), Argentine governments and the private enterprises, which borrowed capital in England for purposes of construction in Argentina - and especially for railroad construction - encouraged the import of materials abroad. This idea matched perfectly with the empirical evidence, but we must add something generally omitted by the literature. The deficit was not only due to the expansion of imports but also due to the fall of exports given the already mentioned fall of prices, which is captured in our export series.

The surplus of the last decade of the $19^{\text {th }}$ century was due to the increase in the volume of exports, both agricultural and cattle products, which facilitated the entrance of gold and the revalorisation of the Argentinean currency (Cortés Conde 1997, p. 167), and a gradual import substitution (for further details, see Dirección General de Comercio e Industria 1927, p. 155). This period also exemplified how the often-mentioned fall in transport costs favoured the massive arrival of Argentine low unit value goods to distant markets ( O'Rourke and Williamson 2000).

As it can be observed, both balances of trade tend to converge after 1893 because the ADGEN increasingly used market prices instead of official prices to value exports. However, our correction of frozen beef and mutton prices suggests higher surpluses during the first years of the $20^{\text {th }}$ century, given that the values of those products were not updated according to market prices in the whole studied period.

The results of the balance of trade estimated with our corrected series of exports and the official series of imports is coherent with the results of a recent research about terms of trade that indicates that after the initial decline of prices, seen since 1880 s, there was a positive tendency between 1894 and 1914, only reversed by the war (Kuntz and Rayes, 2017).

On the other hand, the estimation which combines our corrected export series with the corrected import series of Fernández reveals a less favourable balance of trade. It not only presents more years with deficit but it also shows a lesser margin of surplus when the balance is positive. This is to be expected given that our export series increased the total value of exports in average by 3.3 per cent between 1880 and 1913, while the estimation of Fernández augmented the total value of imports in average by 13.5 per cent during the same period.

The result of the last estimation of the balance of trade is less consistent with the literature since a traditional idea is that the exports tended to be 
higher than imports since the 1890s. Fernandez used corrected prices of 1910-1912, which he applied for the whole period, whereas we used current corrected prices; thus, it is obvious that a better estimation should result from a correction of the import series with current import prices. Actually, beyond the fact that the official series of imports has proved to be more consistent than the series for exports, the former can be appreciably improved with some corrections. The next section is dedicated to proposing a research agenda based on gaps in the specialised literature and the possibilities presented by using the official statistical record.

\section{A BRIEF RESEARCH AGENDA ON OFFICIAL IMPORT STATISTICS}

As we have stated in previous studies, it is necessary to discuss the Argentine economic integration during the so-called «First Globalisation». To do so, information that is as reliable as possible is required. Accordingly, this paper was undertaken to revise the official import statistics and to propose how to improve them.

The reliability of official import data progressed in the last decade of the $19^{\text {th }}$ century for several reasons. Ever since then, imports coming from Uruguay that were not Uruguayan were redistributed, the port of Buenos Aires was modernised and that caused the transhipments in Montevideo to be reduced, the knowledge of imports whose origin was unknown was deepened, the classification criteria for the goods were adjusted and regulations were issued to reduce the errors of customs officials. Even then, however, all of those advances did not eliminate the problems that we have listed: there was still suspicion of smuggling of imports which paid high tariffs, willing or unwilling errors by customs officials, mistaken classification of some products, official prices, maritime origins rather than industrial origins and different units of measurement to record certain goods.

This initial study suggests that the official import statistics can be used, while admitting that it is necessary to make arrangements to improve the reliability and the comparability of the information. First, it is relevant to consider the partners' statistics as complementary. They may help to note more accurately how significant were the factors of smuggling, customs officers' errors and product classification errors. Second, given the wide variety of imports it is advisable to carry out sectorial studies. Third, it would be appropriate to review each of the categories in which the products were included to distinguish the type of consumption to which they were oriented (productive or unproductive). This would also contribute in assessing the extent to which imports were linked to the export sector or the domestic economy. Fourth, a comparison between official prices with prices of the same products in other markets would not only strengthen the discussion about terms of trade but also provide more evidence in order to judge the 
reliability of Argentine trade statistics. We propose to do this by choosing some relevant products of the import basket and follow their tendency through time in order to avoid extrapolating prices from distant periods to very different situations as the corrected series, like those constructed by Fernandez or ECLAC, have done. Fifth, a systematic analysis of tariffs would serve to evaluate whether Argentina fits within the protectionist image of Latin America during this period. Finally, as we have tried to do with the balance of trade, the reconstruction of the import series is significant in order to recalculate different trade indicators.

In summary, understanding the trajectory of Argentine imports during the First Globalisation is still a pending task in the literature, despite a few very meritorious efforts already made. To really comprehend Argentina's integration into the international economy, it is imperative to know how imports, and not just exports, performed.

\section{SUPPLEMENTARY MATERIALS}

For supplementary material/s referred to in this article, please visit https:// doi.org/10.1017/S0212610917000155

\section{SOURCES}

Argentine Official Statistics: General Direction of Statistics (1880-1913): Yearbook. Buenos Aires: GDS.

\section{REFERENCES}

Badia-Miró, M., and Carreras-Marín, A. (2008): «La fiabilidad de la asignación geográfica en las estadísticas de comercio exterior: América Latina y el Caribe (1908-1930)». Revista de Historia Económica/Journal of Iberian and Latin American Economic History 3, pp. 323-354.

Badía-Miró, M.; Carreras-Marín, A., and Rayes, A. (2016): «La diversificación del comercio de exportación latinoamericano, 1870-1913. Los casos de Argentina, Chile y Perú», in M.-A. Lopes, and M. C. Zuleta (eds), Mercados en común. Estudios sobre conexiones, negocios y diplomacia en las Américas (siglos XIX y XX). Mexico: El Colegio de México, pp. 45-77.

BAPTISTA, B., and BÉRTOLA, L. (1999): «Uruguay 1870-1913: indicadores de comercio exterior». Jornadas de la Asociación Uruguaya de Historia Económica, Montevideo.

Beaud, J. P., and Prévost, J. G. (1997): «La forme est le fond: la structuration des appareils statistiques nationaux (1800-1945)». Revue de Synthèse 118 (4), pp. 419-456.

Bértola, L., and Ocampo, J. A. (2013): El desarrollo económico de América Latina desde la Independencia. México: FCE.

Bonino-Gayoso, N.; Tena-Junguito, A., and Willebald, H. (2015): «Uruguay and the First Globalization: On the Accuracy of Export Performance, 1870-1913». Revista de Historia Económica/Joumal of Iberian and Latin American Economic History 33 (2). 
Bulmer Thomas, V. (2010): La historia económica de América Latina desde la independencia. México: FCE.

Bunge, A. (1918): Intercambio económico de la República, 1910-1917. Buenos Aires: Dir. Estadística.

Burgin, M. (1960): Aspectos económicos del federalismo argentino. Buenos Aires: Hachette.

Caputo de astelarra, S. (1984): «La Argentina y la rivalidad comercial entre los Estados Unidos e Inglaterra (1899-1929)». Desarrollo Económico 23 (92), pp. 589-608.

Carreras, A.; Tafunell, X.; Yáñez, C., and Hofman, A. (2003): «El desarrollo económico de América Latina en épocas de globalización - Una agenda de investigación». Serie Estudios Estadísticos y Prospectivos, 24, pp. 1-28.

Carreras-Marín, A. (2008): El comercio internacional textil en 1913: un análisis del comercio intraindustrial. Barcelona: Universidad de Barcelona.

CARReras-Marín, A., and Rayes, A. (2015): «La fiabilidad en la distribución geográfica de las exportaciones argentinas, 1875-1913». América Latina en la Historia Económica 22 (3), pp. 177-212.

CEPAL. (1958): El desarrollo económico de la Argentina. Anexo. Santiago de Chile: CEPAL.

Contés Conde, R. (1974): Hispanoamérica: la apertura del comercio mundial, 1850-1930. Buenos Aires: Paidós.

CoRtés Conde, R. (1979): El progreso argentino 1880-1914. Buenos Aires: Sudamericana.

Cortés Conde, R. (1997): La economía argentina en el largo plazo (Siglos XIX y XX). Buenos Aires: Editorial Sudamericana-Universidad de San Andrés.

Cortés Conde, R. (2003): "Argentina. Las vicisitudes de una economía exportadora», in E. Cárdenas, J. A. Ocampo, and R. Thorp (eds), La era de las exportaciones latinoamericanas. De fines del siglo XIX a principios del siglo XX. Mexico: Fondo de Cultura Económica, pp. 360-417.

Cortés Conde, R.; Halperin Donghi, T., and Gorostegui De Torres, H. (1965): Evolución del comercio exterior argentino I. Exportaciones. Buenos Aires: ITDT.

Della Paolera, G., and Taylor, A. (2003): Tensando el ancla: la Caja de Conversión argentina y la búsqueda de la estabilidad macroeconómica, 1880-1935. Buenos Aires: Fondo de Cultura Económica.

Díaz Alejandro, C. (2002): Ensayos sobre la historia económica argentina. Buenos Aires: Editorial Amorrortu.

Dirección General de Comercio e Industria. (1927): Anuario de la República Argentina. Nociones útiles. 1926. Buenos Aires: DGCI.

Ducoing, C., and Tafunell, X. (2013): «Formación bruta de capital en bienes de equipo en Chile, 1856-1930. Fuentes nacionales y extranjeras». América Latina en la Historia Económica 20 (1), pp. 5-34.

Federico, G., and Tena-Junguito, A. (1991): «On the Accuracy of Foreign Trade Statistics (1909-1935): Morgenstern Revisited». Explorations in Economic History 28 , pp. $259-273$.

Federico, G., and Tena-Junguito, A. (2016): «World Trade, 1800-1938: a New Data-Set». European Historical Economic Society Working Papers in Economic History 93.

FERNÁNDEZ, A. (2001): Las exportaciones españolas a la argentina: un enfoque comparativo (1880-1935). Barcelona: Universidad de Barcelona.

Fodor, J., and O'connell, A. (1973): «La Argentina y la economía atlántica en la primera mitad del siglo XX». Desarrollo Económico 13 (49), pp. 3-65.

Ford, A. (1966): El patron-oro: 1880-1914. Inglaterra y Argentina. Buenos Aires: Editorial del Instituto. 
Francis, J. (2017): "Globalisation, the Terms of Trade, and Argentina's Expansion in the Long Nineteenth Century». Journal of Latin American Studies 49, (4), pp. 709-738.

GelLeR, L. (1975): «El crecimiento industrial argentino hasta 1914 y la teoría del bien primario exportable», in M. Giménez Zapiola (ed.), El régimen oligárquico: materiales para el estudio de la realidad argentina (hasta 1930). Buenos Aires: Amorrortu, pp. 152-200.

Gerchunoff, P., and Llach, L. (2007): El ciclo de la ilusión y el desencanto. Un siglo de políticas económicas argentinas. Buenos Aires: Emecé Editores.

Gerchunoff, P., and Llach, L. (2008): "Antes y después del "corto siglo XX". Dos globalizaciones latinoamericanas (1850-1914 y 1980s-2000s)». XXI Jornadas de la Asociación Argentina de Historia Económica. Caseros: Asociación Argentina de Historia Económica, pp. 1-52.

González Bollo, H. (2014): La fábrica de las cifras oficiales del Estado argentino (18691947). Bernal: Universidad Nacional de Quilmes.

Halperin Donghi, T. (1977): «Argentina», in R. Cortés Conde, and S. Stein (eds), Latin America. A Guide to Economic History, 1830-1930. Berkeley, CA: University of California Press, pp. 51-162.

Hora, R. (2000): «Terratenientes, empresarios industriales y crecimiento industrial en la Argentina: los estancieros y el debate sobre el proteccionismo (1890-1914)». Desarrollo Económico 159, pp. 465-492.

Kellenber, D., and Levinson, A. (2016): «Misreporting Trade: Tariff Evasion, Corruption, and Auditing Standards». National Bureau of Economic Research Working Papers 22593.

Kuntz-Ficker, S. (2007): El comercio exterior de México en la era del capitalismo liberal. 1870-1929. México: El Colegio de México.

KunTz-FICKER, S. (2010): Las exportaciones mexicanas durante la primera globalización. 1870-1929. México: El Colegio de México.

Kuntz-Ficker, S., and RaYes, A. (2017): "The Contribution of Argentine Exports to the Economy, 1875-1929», in S. Kuntz-Ficker (ed.), Latin America's First Export Era Revisited: Reassessing its Economic Contribution. London: Palgrave, pp. 52-84.

KunTZ-Ficker, S., and RaYes, A. (unpublished): «El valor de retorno de las exportaciones argentinas, 1880-1929». Unpublished.

Latzina, F. (1905): Estadística retrospectiva del comercio exterior argentino 1875-1904. Buenos Aires: Compañía Sud Americana de Billetes de Banco.

Latzina, F. (1914): Sinopsis estadística argentina. Buenos Aires: Edited by Compañía Sudamericana de Billetes de Banco.

Martinez, M, and Lewandowski, M. (1911): The Argentine of the Nineteenth Century. London: Fisher Unwin.

Mentz, R. (1991): "Sobre la historia de la estadística oficial argentina». Estadística española 218, pp. 501-532.

Míguez, E. J. (2008): Historia económica de la Argentina. De la conquista a la crisis de 1930. Buenos Aires: Sudamericana.

Míguez, E. J., and Rayes, A. (2014): «La naturaleza de la dependencia, la dependencia de la naturaleza. Las exportaciones argentinas 1890-1938 en perspectiva comparada». Desarrollo Económico 211, pp. 313-344.

Morgenstern, O. (1953): On the Accuracy of Economic Observations. Princeton, NJ: Princeton University Press.

O’Rourke, K., and Williamson, J. (2000): Globalization and History: The Evolution of a Nineteenth-Century Atlantic Economy. Cambridge: MIT. 
Otero, H. (2006): Estadística y nación: una historia conceptual del pensamiento censal de la Argentina moderna, 1869-1914. Buenos Aires: Prometeo.

Pillado, R. (1906): Política comercial argentina. Contribución a su estudio. Buenos Aires: Talleres Gráficos de la Oficina Meteorológica Argentina.

Platt, D.C.M. (1971): "Problems in the Interpretation of Foreign Trade Statistics Before 1914». Journal of Latin American Studies 3 (2), pp. 119-130.

RAYEs, A. (2013): "En las puertas del Dorado. Las exportaciones argentinas, 1890-1913», Buenos Aires: Universidad Torcuato Di Tella.

RaYes, A. (2015a): "La estadística de las exportaciones argentinas, 1875-1913. Nuevas evidencias e interpretaciones». Investigaciones de Historia Económica 11 (1), pp. 31-42.

Rayes, A. (2015b): "Medio siglo mediante. La historiografía y la historia de las exportaciones argentinas durante la Primera Globalización». Boletín del Instituto de Historia Argentina y Americana "Dr. Emilio Ravignani" 43, pp. 184-207.

RAYES, A. (2016): «La construcción de las estadísticas oficiales argentinas de exportación, c. 1880-1930». Estudios Sociales del Estado 4, pp. 96-120.

Regalsky, A. (2011): «El proceso económico», in E. Míguez (coord.), Argentina. La apertura al mundo, 1880-1930. Madrid: Santillana-Fundación Mapfre, pp. 151-206.

Rubio, M., and Folchi, M. (2012): «On the Accuracy of Latin American Trade Statistics: A Non-Parametric Test for 1925», in C. Yáñez, and A. Carreras (eds), The Economies of Latin America: New Cliometric Data. London: Pickering and Chatto, pp. 41-57.

Tena-Junguito, A. (1992): Las estadísticas históricas del comercio internacional: fiabilidad y comparabilidad (1890-1960). Madrid: Banco de España.

Tena-Junguito, A., and Willebald, H. (2013): "On the Accuracy of Export Growth in Argentina, 1870-1913». Economic History of Developing Regions 28 (1), pp. 28-68.

VÁzQuez Presedo, V. (1971): El caso argentino: migración de factores, comercio exterior y desarrollo, 1875-1914. Buenos Aires: EUDEBA.

Williams, J. (1969): Argentine International Trade Under Inconvertible Paper Money, 1880-1900. New York: Greenwood.

Winograd, C., and Vèganzones, M. (1997): Argentina en el siglo XX: crónica de un crecimiento anunciado. París: OCDE.

Woolf, S. (1989): «Statistics and the Modern State». Comparative Studies in Society and History 31 (3), pp. 588-604.

YÁNEZ, C., and BADÍA-Miró, M. (2007): «Las importaciones de relojes y automóviles en América Latina durante 1925. Una aproximación desde el punto de vista de la renta y su distribución». Revista de Historia Industrial 35, pp. 143-164. 